\title{
ECMO cannula-associated infections: interest of cannula swab and subcutaneous needle aspirate samples for prediction of cannula tip culture
}

\author{
Hadrien Winiszewski ${ }^{1,2^{*}}$ (D), Charles Boyadjian ${ }^{1}$, Guillaume Besch ${ }^{2,3}$, Andrea Perrotti ${ }^{2,4}$ and Gaël Piton ${ }^{1,2}$
}

* Correspondence: hadrien51@ hotmail.com

${ }^{1}$ Medical Intensive Care Unit, Besançon University Hospital, Besançon, France

${ }^{2}$ EA3920, University of Franche Comté, Besançon, France Full list of author information is available at the end of the article
Keywords: ECMO, Cannula infection, Diagnosis

To the Editor,

In a recent review published in Intensive Care Medicine, Abrams et al. listed the research agenda of extracorporeal membrane oxygenation (ECMO)-associated infections. One of the questions was "how should cannula-associated infection be defined?" [1].

Literature on ECMO cannula-associated infections is very scarce [2, 3], and no clear definition is available. Then, diagnostic workup of cannula-related infections is currently derived from central catheter-related infection guidelines. For catheter-related infection, a positive catheter tip culture is a diagnostic criterion [4]. However, this attitude cannot be fully transposed to ECMO cannula-related infections, as cannula cannot be easily removed and changed for tip culture. We therefore aimed at evaluating the performance of cannula swab and subcutaneous needle aspirate for predicting the results of the cannula's tip culture.

In this prospective observational pilot study, patients treated by ECMO at the Besancon University Hospital (France) were enrolled. When patients had sepsis or local signs of cannula-associated infection, cannula swab and subcutaneous needle aspirate (Fig. 1d) of both arterial and venous cannulas were systematically obtained for culture. For subcutaneous needle aspirate, after cleaning with an antiseptic solution, a catheter for peripheral venous access was inserted on 1 to $3 \mathrm{~cm}$ along the ECMO cannula. If no exudate was aspirated, $1 \mathrm{~mL}$ of saline was injected and re-aspirated. The aspirate was sent for bacterial culture. Quantitative culture was not performed, and all positive cultures were considered. At the time of ECMO weaning, the cannula tips were also collected for culture. Culture of cannula swab and subcutaneous needle aspirate were considered as "positive AND fully correspondent" with the cannula tip if it detected all the pathogens of the cannula tip. Culture of cannula swab and subcutaneous needle aspirate were considered as "positive AND not fully correspondent" if the culture was positive but some pathogens were lacking or were different.

(c) The Author(s). 2020 Open Access This article is licensed under a Creative Commons Attribution 4.0 International License, which permits use, sharing, adaptation, distribution and reproduction in any medium or format, as long as you give appropriate credit to the original author(s) and the source, provide a link to the Creative Commons licence, and indicate if changes were made. The images or other third party material in this article are included in the article's Creative Commons licence, unless indicated otherwise in a credit line to the material. If material is not included in the article's Creative Commons licence and your intended use is not permitted by statutory regulation or exceeds the permitted use, you will need to obtain permission directly from the copyright holder. To view a copy of this licence, visit http://creativecommons.org/licenses/by/4.0/. 


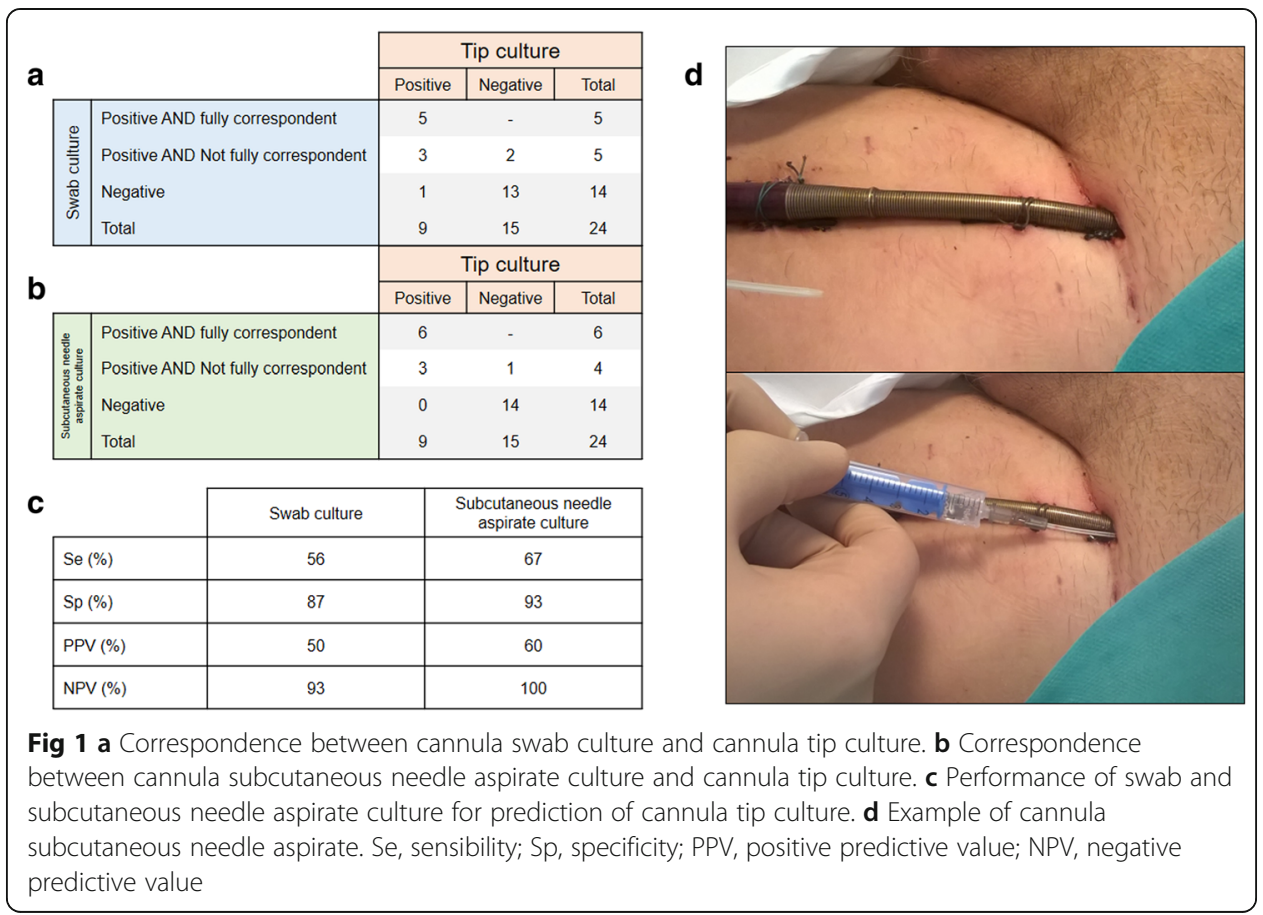

We included 24 patients, aging 64 years old [IQR 53-70], 71\% males, with 21 VA and 3 VV ECMO. Cannulation technique was mostly surgical (20/24), and 19 patients had both cannulas in the same groin. Nine patients (38\%) had a positive tip culture, including 5 with associated bacteremia to the same pathogen. Among them, culture was positive for both of the cannula's tips in 7 patients and positive for only one of the cannula's tip in 2 patients. Enterobacteriaceae and enterococci were the most common pathogens detected on cannula tips. Median duration between ECMO start and local sampling was 9 [4-11] days. Median duration between local sampling and tip culture was 4 [IQR 2-6] days. Sensibility and positive predictive value for cannula tip positive culture were 56 and 50\% for swab and 67 and $60 \%$ for subcutaneous needle aspirate (Fig. 1a, c). Specificity and negative predictive value for cannula tip positive culture were 87 and $93 \%$ for swab and 93 and $100 \%$ for subcutaneous needle aspirate (Fig. 1b, c).

Our data suggest that swab or subcutaneous needle aspirate culture might be useful to predict a negative cannula tip culture. Therefore, the combination of both samples, easily obtained on the bedside, might be of interest to rule out ECMO cannula-related infection.

\section{Abbreviations}

ECMO: Extracorporeal membrane oxygenation

\section{Acknowledgements}

We thank Gilles Capellier who participated in the manuscript writing and Martin Jeanney who collected the data.

\section{Authors' contributions}

HW and CB wrote the protocol. CB collected the data. HW, GB, GB, AP, and GP wrote the manuscript. The authors read and approved the final manuscript. 
Availability of data and materials

The datasets used and/or analyzed during the current study are available from the corresponding author on reasonable request.

\section{Ethics approval and consent to participate}

This work was considered as an Evaluation of Professional Practices (EPP), performed for the description of practices, with the aim of improving the care. According to French law, no consent for the study was required because this EPP did not modify existing diagnostic or therapeutic strategies. This EPP was registered by the Clinical Research and Innovation Department of the Besançon Teaching Hospital.

\section{Consent for publication}

Not applicable

\section{Competing interests}

The authors declare no conflict of interest.

\section{Author details}

${ }^{1}$ Medical Intensive Care Unit, Besançon University Hospital, Besançon, France. ${ }^{2}$ EA3920, University of Franche Comté, Besançon, France. ${ }^{3}$ Surgical Intensive Care Unit, Besançon University Hospital, Besançon, France. ${ }^{4}$ Cardiac Surgery Unit, Besançon University Hospital, Besançon, France.

Received: 10 June 2020 Accepted: 15 July 2020

Published online: 23 July 2020

\section{References}

1. Abrams D, Grasselli G, Schmidt M, Mueller T, Brodie DECLS-associated infections in adults: what we know and what we don't yet know. Intensive Care Med. 25 nov 2019;

2. Schmidt M, Brechot N, Hariri S, Guiguet M, Luyt CE, Makri R, et al. Nosocomial infections in adult cardiogenic shock patients supported by venoarterial extracorporeal membrane oxygenation. Clin Infect Dis. 15 déc 2012;55(12):1633-41.

3. Thomas G, Hraiech S, Cassir N, Lehingue S, Rambaud R, Wiramus S, et al. Venovenous extracorporeal membrane oxygenation devices-related colonisations and infections. Ann Intensive Care. 7 nov 2017;7(1):111.

4. Timsit J-F, Rupp M, Bouza E, Chopra V, Kärpänen T, Laupland K et al (2018) A state of the art review on optimal practices to prevent, recognize, and manage complications associated with intravascular devices in the critically ill. Intensive Care Med. juin 44(6):742-759

\section{Publisher's Note}

Springer Nature remains neutral with regard to jurisdictional claims in published maps and institutional affiliations.

\section{Submit your manuscript to a SpringerOpen ${ }^{\circ}$ journal and benefit from:}

- Convenient online submission

- Rigorous peer review

- Open access: articles freely available online

High visibility within the field

- Retaining the copyright to your article 